\title{
PENGEMBANGAN BOLA BANEL SEBAGAI MEDIA PEMBELAJARAN BOLA VOLI DI SDN 1 BULUAGUNG
}

\author{
Handri Khoirul Mustofa', Ardhi Kurniawan² \\ 1,2 Program Studi Pendidikan Jasmani STKIP PGRI Trenggalek \\ Email: akaramadhan@gmail.com \\ DOI: https://doi.org/10.36526/kejaora.v5i1.763
}

\begin{abstract}
ABSTRAK
Permasalahan tersebut antara lain (1) banyak peserta didik pada saat melakukan passing bawah merasa lengannya sakit (2) kurangnya sarana dan prasarana. Berdasarkan dari latar belakang masalah dan pembatasan masalah yang diuraikan di atas maka penulis dapat merumuskan tujuan dalam penelitian ini yaitu "Apakah media bola voli yang dimodifikasi dengan Banel bisa dijadikan media pembelajaran bola voli bagi siswa SDN 1 Buluagung. Penelitian ini merupakan penelitian pengembangan. Pengembangan ini dilakukan melalui berbagai tahapan: pendahuluan analisis, desain, melakukan pengembangan produk, implementasi (penerapan), dan yang terakhir evaluasi produk. Subjek uji coba peserta didik SD Negeri 1 Buluagung kelas IV yang berjumlah 25 siswa. Pada hasil uji coba kelompok kecil dengan 10 peserta hampir semua penilaian mendapat nilai kategori baik, hanya sebagian yang mendapat penilaian cukup karena mendapat nilai persentase 60 - 70\%. Rata-rata penilaian hasil uji coba produk kelompok kecil sebesar $76 \%$. Sedangkan untuk hasil uji coba kelompok besar dengan 25 peserta didik semua penilaian mendapat nilai kategori baik. Rata-rata penilaian hasil uji coba produk kelompok besar sebesar $87 \%$.
\end{abstract}

Kata Kunci : Pengembangan, Media pembelajaran bola voli, Bola banel

\section{PENDAHULUAN}

Setelah melakukan observasi awal di SDN 1 Buluagung, terdapat permasalahan di SD sebagai berikut banyak peserta didik pada saat melakukan passing bawah dalam permainan bola voli merasa tangannya sakit dan kurangnya sarana dan prasarana di SD tersebut, kemampuan passing peserta didik masih rendah. Faktor yang melatarbelakangi masalah tersebut sering terjadi di lapangan yang berkaitan dengan sarana dan prasarana yang digunakan dalam pembelajaran terutama yang berkaitan dengan ketersediaan dan spesifikasi alat yang digunakan dalam pembelajaran bola voli khususnya passing bawah. Pada pembelajaran bola voli ditemukan bahwa bola yang digunakan hanya tersedia 2 buah sehingga pembelajaran bola voli khususnya passing bawah kurang optimal. Berikut ini standar ukuran bola voli yang digunakan dalam pertandingan resmi, ukuran keliling bola $65-67 \mathrm{~cm}$, berat bola voli $260-280$ gram, tekanan bola $0.30-0.325 \mathrm{~kg} / \mathrm{cm}(4.26-4.61 \mathrm{psi}$,
294.3-318.82 mbar atau $\mathrm{hPa}$ ) diameter bola voli selitar $18-20 \mathrm{~cm}$. Penggunaan bola voli yang kurang, merupakan sumber permasalahan yang menjadi fokus peneliti.

Seperti yang peneliti amati selama ini pada pembelajaran passing bawah di SDN 1 Buluagung, masih mengalami beberapa permasalahan. Permasalahan tersebut antara lain (1) banyak peserta didik pada saat melakukan passing bawah merasa tanganya sakit (2) kurangnya sarana dan prasarana (3) kurangnya motivasi peserta didik dalam pembelajaran (4) kemampuan passing bawah siswa masih sangat rendah. Mengingat jumlah sarana dan prasaran yang kurang memadai dan banyak peserta didik saat melakukan passing merasa tangannya sakit, peneliti berinisiatif mengembangkan media bola voli dengan menggunakan bola voli yang dimodifikasi dengan menggunakan Banel tersebut. Peneliti memilih pengembangan media bola voli yang dimodifikasi menggunakan Banel karena beban yang ringan dan disesuaikan dengan kenyamanan 
Jurnal Kejaora: Jurnal Kesehatan Jasmani dan Olah Raga

ISSN: 2541-5042 (Online)

ISSN: 2503-2976 (Print)

Volume 5 Nomor 1, Edisi April 2020

siswa. Media ini sangat aman bagi peserta didik dan juga dalam pembuatan bola voli yang dikembangkan dengan Banel, bola voli yang telah dimodifikasi tidak memerlukan biaya yang banyak dan mudah didapat. Melalui pengembangan media bola voli yang telah dimodifikasi pada pendidikan jasmani olahraga ini diharapkan para peserta didik di SDN 1 Buluagung dapat melakukan teknik passing bawah yang benar. Dengan peralatan yang sederhana dan menarik perhatian peserta didik maka dapat membangkitkan motivasi belajar peserta didik, sehingga peserta didik dapat lebih aktif gerak mengikuti proses pembelajaran pendidikan jasmani dan olahraga cabang olahraga bola voli khususnya passing bawah.

\section{METODE}

Pada penelitian ini penelitian menggunakan penelitian dengan model pengembangan ADDIE. Menurut Branch (2009:1-3) model pengembangan ADDIE adalah salah satu model desain sistem pembelajaran yang memperlihatkan tahapantahapan dasar untuk mengembangkan dan memvalidasi produk-produk yang digunakan dalam pendidikan, Terdapat 5 lima tahap yaitu:

\section{Analysis}

SDN 1 Buluagung sarananya sangat terbatas dan banyak peserta didik yang merasa kesakitan pada saat melakukan passing bawah, terutama pada cabang olahraga bola voli, kendala ini bisa dilihat dari sekian banyak peserta didik yakni dari sekian banyak peserta didik yakni dari kelas IV di SDN 1 Buluagung yang berjumlah kurang lebih 25 peserta didik hanya mempunyai sbuah Bola voli. dengan adanya kendala tersebut sangat dibutuhkan media pembelajaran untuk membantu proses pembelajaran di SDN 1 Buluagung.

\section{Design}

Untuk mengatasi masalah media pembelajaran untuk bola voli, maka saya sebagai peneliti mencari solusi agar pembelajaran pendidikan jasmani bisa berjalan dengan lancar khususnya materi

bola voli, yaitu dengan cara membuat modifikasi pada bola sehingga bisa digunakan dalam pembelajaran olahraga di SDN 1 Buluagung. Adanya modifikasi Bola diharapkan bisa membantu guru dalam melaksanakan pembelajaran olahraga di SDN 1 Buluagung. Media ini dimodifikasi sedemikian rupa sehingga bisa menjadi solusi permasalahan yang ada di sekolah SDN 1 Buluagung.

\section{Development}

Setelah produk jadi sebelum diujicobakan, peneliti melakukan validasi kepada ahli media dan ahli bola voli apakah media ini sudah layak digunakan. Selanjutnya apabila mendapat saran dari ahli media maka peneliti melakukan revisi produk agar lebih sempurna sesuai masukan dari ahli.

\section{Implementation}

Pada tahap ini peneliti menerapakan apa yang sudah direncanakan dan dikembangkan untuk diuji cobakan kepada peserta didik, untuk mengetahui apakah media yang dikembangkan ini sudah sesuai apa yang direncanakan dan berguna untuk menbantu proses pembelajaran. Tahap uji coba produk peneliti melakukan dengan cara uji coba kelompok kecil 10 peserta didik dan uji kelompok besar 25 peserta didik.

\section{Evaluation}

Tahap evaluasi merupakan tahapan akhir dari sebuah penelitian, pada tahap evaluasi ini dari hasil uji coba akhir yang berupa angket tersebut maka peneliti membuat kesimpulan berdasarkan hasil penelitian apakah media pembelajaran yang dikembangkan sudah berhasil sesuai dengan harapan peneliti. Dengan demikian peneliti mengetahui seberapa besar presentasi keberhasilan media yang dikembangakan peneliti itu.

\section{HASIL DAN PEMBAHASAN}

Dari hasil wawancara guru PJOK di SDN 1 Buluagung peneliti mendapatkan informasi terkait permasalahan yang ada di sekolah tersebut, diantaranya yaitu: 1) terdapat sarana yang belum memadai, 2) kurangnya sarana dibandingkan dengan 
Jurnal Kejaora: Jurnal Kesehatan Jasmani dan Olah Raga

ISSN: 2541-5042 (Online)

ISSN: 2503-2976 (Print)

Volume 5 Nomor 1, Edisi April 2020

jumlah siswa, 3) sebagian siswa kurang aktif mengikuti pembelajaran bola voli karena pada saat passing bawah merasa tanganya sakit, karena bola yang digunakan bola standar orang dewasa, 4) belum pernah modifikasi media bola sesuai dengan bentuk aslinya.

Maka dari itu, peneliti membuat pengembangan media bola voli yang di modifikasi menggunakan Banel sehingga dapat dijadikan alternatif dalem proses pembelajaran bola voli khususnya passing bawah. Peneliti meminta izin kepada Kepala SDN 1 Buluagung dan guru pendidikan jasmani dan olahraga untuk melakukan penelitian disana. Sehingga nanti bisa diketahui hasil dari produk media yang sudah dibuat peneliti apakah dapat dijadikan sebagai altenatife dalam pembelajaran bola voli. Dari hasil validasi ahli pembelajaran setelah saya validasi produk Banel ada beberapa perbaikan yaitu: 1). bentuk bola voli sudah menyerupai yang asli tetapi apabila terkena angin agak melayang, 2). Pembelajaran bola voli dengan alat yang dimodifikasi siswa sangat antusias dan merasa senang.

Dari hasil angket dengan persentase penilaian untuk ahli media pembelajaran yaitu $72.94 \%$. Dengan hasil ini maka produk ini layak sehingga produk media Banel dapat langsung digunakan untuk diujikan. Hasil validasi ahli media pembelajaran, uji ahli dilakukan untuk mengetahui kelayakan bola berbahan dasar bola plastik yang dlapisi kain flannel untuk pembelajaran di SD Negeri 1 Buluagung. Uji ahli melibatkan ahli media pembelajaran. Produk awal pengembangan model pembelajaran bola voli melalui modifikasi alat bantu media Banel sebelum diujicobakan dalam uji kelompok kecil, produk yang dihasilkan perlu dilakukan validasi oleh ahli yang sesuai dengan bidang penelitian ini. Peneliti melibatkan ahli media pembelajaran ada dua perbaikan atau revisi: revisi pertama (1). Bagian yang direvisi untuk warna bola jangan di sesuaikan dengan aslinya, alasan di revisi Biar mempunyai ciri khas tersendiri, saran perbaikan Diganti warna agar menarik, dan disesuaikan. (2). Bagian yang direvisi Untuk ketebalan kain flannel, alasan direvisi Agar lebih halus dan jika bola terbentur tidak

cepat rusak, saran perbaikan Carilah kain flannel yang agak tebal. Revisi kedua (1). Bagian yang direvisi tekanan udara untuk pantulan bola, alasan direvisi agar sesuai dengan bola aslinya dan pantulan bola semakin tinggi, saran perbaikan dilapisi spon sebelum dilapisi kain flanel.

Dari hasil angket dengan persentase penilaian untuk ahli media pembelajaran yaitu revisi pertama $78 \%$ dan revisi kedua $82 \%$, Dengan hasil ini maka produk ini layak sehingga produk media Banel dapat langsung digunakan untuk diujikan skala kecil dan besar. Dari hasil kelompok kecil media Banel yang saya lakukan di SD Negeri 1 Buluagung dengan peserta 10 siswa di dapatkan hasil sebagai berikut: hasil penilaian kuesioner angket uji coba kelompok kecil dengan table persentase penilaian untuk siswa yaitu $76 \%$, Dengan hasil ini maka dapat disimpulkan produk ini layak untuk digunakan. Hasil kelompok besar media Banel yang saya lakukan di SD Negeri 1 Buluagung dengan peserta 25 siswa di dapatkan hasil sebagai berikut: hasil penilaian kuesioner angket uji coba kelompok besar dengan table persentase penilaian untuk siswa yaitu $87 \%$, Dengan hasil ini maka dapat disimpulkan produk ini layak untuk digunakan.

Tabel 1. Kriteria Persentase

\begin{tabular}{ccc}
\hline No. & Rentang & Kriteria \\
\hline 1 & $76 \%-100 \%$ & Baik \\
\hline 2 & $56 \%-75 \%$ & Cukup \\
\hline 3 & $40 \%-55 \%$ & Kurang baik \\
\hline 4 & $<40 \%$ & Tidak baik \\
\hline
\end{tabular}

Hasil produk awal setelah mendapatkan informasi, peneliti akan mengembangkan produk banel yang nantinya akan digunakan untuk pembelajaran bola voli di SD Negeri 1 Buluagung. Produk awal dibuat berdasarkan pada kajian teori yang kemudian dievaluasi oleh satu ahli media pembelajaran.

\section{KESIMPULAN}

Berdasarkan hasil penelitian di SD Negeri 1 Buluagung dapat disimpulkan bahwa modifikasi media banel dapat digunakan untuk pengganti bola voli yang asli untuk pembelajaran materi passing bawah. Hal ini ditunjukan dengan hasil 2 kali uji coba 
Jurnal Kejaora: Jurnal Kesehatan Jasmani dan Olah Raga

ISSN: 2541-5042 (Online)

ISSN: 2503-2976 (Print)

Volume 5 Nomor 1, Edisi April 2020

kelompok kecil dan besar dengan hasil penilaian untuk uji coba kelompok kecil ratarata sebesar $76 \%$, sedangkan untuk hasil penilaian uji coba kelompok besar rata-rata sebesar $87 \%$. Dengan hasil demikian media banel berbentuk bola voli ini mendapat kategori baik dan bisa digunakan. Modifikasi banel ini memiliki diameter kurang lebih $65 \mathrm{~cm}$ dan berat 150 gram. serta kombinasi warna yang menarik. Sehingga lebih menarik untuk dimainkan.

Pembelajaran bola voli khususnya passing bawah menggunakan media bola plastik yang dilapisi spon dan kain flannel sangat efektif dan sesuai dengan kerakteristik siswa, karena pembelajaran ini memiliki kelebihan, yaitu bola yang digunakan lebih ringan dari pada bola aslinya, bola yang digunakan harganya tidak mahal sehingga mudah untuk mendapatkannya, Dengan kombinasi warna yang menarik siswa menjadi lebih antusias dalam mengikuti pembelajaranbola voli. Dalam pembelajaran bola voli yang menggunakan bola plastik yang dilapisi spon dan kain flanel siswa sudah merasa tidak takut lagi untuk melakukan passing bawah bola voli, dikarenakan bolanya dimodifikasi sedemikian rupa sehingga lebih nyaman dipakai siswa. Bahan yang digunakan untuk membuat media banel ini mudah diperoleh sehingga guru penjas tidak merasa kesulitan jika ingin membuat media pembelajaran ini.

\section{SARAN}

Bagi peneliti yang akan melakukan penelitian serupa sebagai alat pengganti bola voli yang asli maka peneliti menyarankan:

1. Memperluas ruang lingkup penelitian.

2. Perlu dilakukan evaluasi dampak media pembelajaran terhadap peningkatan hasil pembelajaran.

3. Perlu dilakukan penelitian lanjutan untuk mengetahui berapa lama ketahanan media banel ini digunakan, serta penelitian pengembangan media banel yang bisa digunakan di musim hujan.

\section{UCAPAN TERIMA KASIH}

Peneliti mengucapkan banyak terima kasih kepada Kepala SD Negeri 1 Buluagung yang telah memberikan ijin untuk melakukan

penelitian, Guru PJOK SD Negeri 1 Buluagung bersama siswa-siswanya, dan bapak Muhammad Soleh Fudin selaku ahli media.

\section{DAFTAR PUSTAKA}

Manan, B. (2017). Penggunaan Media Modifikasi Bola Plastik Untuk Meningkatkan Hasil Belajar Teknik Dasar Passing Bawah Dalam Bolavoli Pada Siswi Kelas VII di SMP Negeri 3 Pabuaran 2017. Seminar Nasional Pendidikan Sukabumi.

Musfiqon. (2012). Pengembangan Media dan Sumber Pembelajaran. Malang: Kanisius.

Rahayu, E.T. (2013). Strategi Pembelajaran Pendidikan Jasmani. Bandung: Alfabeta.

Robert, M.B. (2009). Instructional Design: The ADDIE Approac. New York: Springer.

Rosdiani, D. (2012). Model Pembelajaran langsung dalam Pendidikan Jasmani dan Kesehatan. Bandung: Alfabeta.

Setiyono, Y. (2019). Pedoman Penyusun Penelitian. Trenggalek: STKIP PGRI Trenggalek.

Sudijono. (2014). Pengantar Statistik Pendidikan. Jakarta: Raja Grafindo Persada

Sugiyono. (2011). Metode Penelitian Kuantitatif, Kualitatif dan $R$ \& $D$ Bandung: Alfabeta

Sulilowati. (2012). Penggunaan Bola Plastik dapat Meningkatkan Hasil Belajar Passing Bawah pada Permainan Bola Voli pada Siswa Kelas IV Sekolah Dasar Negeri 01 Kalitorong. Skripsi. Prodi Pendidikan Jasmani Kesehatan dan Rekreasi Universitas Negeri Semarang.

Sunardi dan Kardiyanto, D.W. (2015). Bola Voli. Cetakan ke 1. Surakarta: UNS Press.

Wiarto. (2015). Media Pembelajaran dalam Pendidikan Jasmani, Yogyakarta: Laksitas

Winarno, M. E. (2011). Metodologi Penelitian dalam Pendidikan Jasmani. Malang: Media Cakrawala Utama Press. 
Jurnal Kejaora: Jurnal Kesehatan Jasmani dan Olah Raga

ISSN: 2541-5042 (Online)

ISSN: 2503-2976 (Print)

Volume 5 Nomor 1, Edisi April 2020

Yusmar, A. (2017). Upaya Peningkatan Teknik Permainan Bolavoli Melalui Modifikasi Permainan Siswa Kelas $X$ SMA Negeri 2 Kampar. Jurnal PAJAR (Pendidikan Dan

Pengajaran), 1(1), 143-152. 